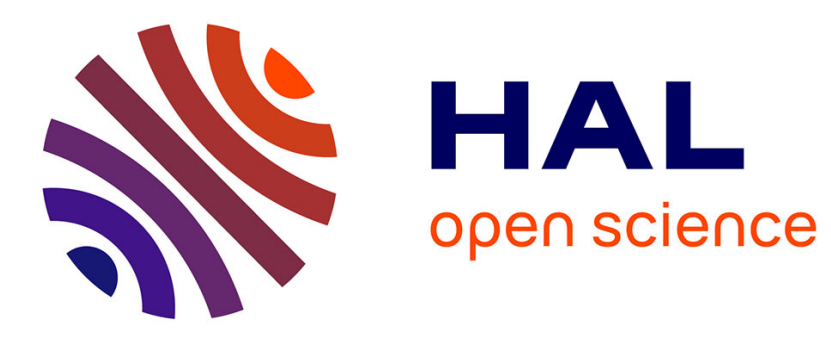

\title{
Xylophagous insects of the wooden floor of Camelin block (Fréjus, France): An interdisciplinary approach combining archaeology and anthraco-entomology
}

\author{
Magali Toriti, Aline Durand, Pierre Excoffon, Fabien Fohrer
}

\section{- To cite this version:}

Magali Toriti, Aline Durand, Pierre Excoffon, Fabien Fohrer. Xylophagous insects of the wooden floor of Camelin block (Fréjus, France): An interdisciplinary approach combining archaeology and anthracoentomology. Quaternary International, 2021, 593-594, pp.60-70. 10.1016/j.quaint.2020.09.034 . halshs-02949761v2

\section{HAL Id: halshs-02949761 \\ https://shs.hal.science/halshs-02949761v2}

Submitted on 10 Feb 2021

HAL is a multi-disciplinary open access archive for the deposit and dissemination of scientific research documents, whether they are published or not. The documents may come from teaching and research institutions in France or abroad, or from public or private research centers.
L'archive ouverte pluridisciplinaire HAL, est destinée au dépôt et à la diffusion de documents scientifiques de niveau recherche, publiés ou non, émanant des établissements d'enseignement et de recherche français ou étrangers, des laboratoires publics ou privés. 


\title{
Xylophagous insects of the wooden floor of Camelin block (Fréjus, France): an interdisciplinary approach combining archaeology and anthraco-entomology
}

\author{
Magali Toriti ${ }^{1}$, Aline Durand ${ }^{2}$, Pierre Excoffon ${ }^{3}$, Fabien Fohrer ${ }^{4}$ \\ Corresponding author: Magali Toriti, mag.toriti@gmail.com
}

Fichier produit par les auteurs

Résultats publiés dans

Quaternary International, on line September $25^{\text {th }}$

$\underline{10.1016 / \text { i.quaint.2020.09.034) }}$

\footnotetext{
${ }^{1}$ Doctor and associate researcher, Le Mans University - CReAAH UMR 6566 - Maison des Sciences humaines et sociales, Avenue Olivier Messiaen, 72085 Le Mans cedex 9, France

${ }^{2}$ Professor, Le Mans University - CReAAH UMR 6566 - Maison des Sciences humaines et sociales, Avenue Olivier Messiaen, 72085 Le Mans cedex 9, France

${ }^{3}$ Director of the Archaeology and Heritage department of Fréjus city (SAPVF), 702 avenue du XVe Corps 83600 Fréjus, France

${ }^{4}$ Entomologist, CICRP, Interdisciplinary Center for the Conservation and Restoration of Heritage, 23 rue Guibal, 13003 Marseille, France
} 


\title{
Xylophagous insects of the wooden floor of Camelin block (Fréjus, France): an interdisciplinary approach combining archaeology and anthraco-entomology
}

\author{
Magali Toriti ${ }^{1}$, Aline Durand ${ }^{2}$, Pierre Excoffon ${ }^{3}$, Fabien Fohrer ${ }^{4}$ \\ ${ }^{1}$ Doctor and associate researcher, Le Mans University - CReAAH UMR 6566 - Maison des Sciences humaines et sociales, Avenue \\ Olivier Messiaen, 72085 Le Mans cedex 9, France \\ ${ }^{2}$ Professor, Le Mans University - CReAAH UMR 6566 - Maison des Sciences humaines et sociales, Avenue Olivier Messiaen, 72085 \\ Le Mans cedex 9, France \\ ${ }^{3}$ Director of the Archaeology and Heritage department of Fréjus city (SAPVF), 702 avenue du XVe Corps 83600 Fréjus, France \\ ${ }^{4}$ Entomologist, CICRP, Interdisciplinary Center for the Conservation and Restoration of Heritage, 23 rue Guibal, 13003 Marseille, \\ France
}

Corresponding author: Magali Toriti, mag.toriti@gmail.com

\begin{abstract}
Preventive excavation in the ancient Forum Iulii city (Fréjus, southern France) in 2013 revealed a housing block where a very well preserved charred wooden floor was discovered. It was laid in a house dating back to the first half of the 1st century $A D$ and used as the floor of a room decorated with painted plaster. It was destroyed by fire around 70 AD. The ligneous species used for its construction (Aleppo pine, Scots pine, beech and fir) were characterized by anthracological analysis. Numerous traces of xylophagous insects and lignivorous fungi were observed. Their identification, their number and their distribution in the floor open on to very interesting new interpretations for both anthracologists and archaeologists as regards the condition of timber, the original source of the infestation, and the historical record of the building. This study is a direct and unprecedented application of a key for identifying traces of wood-boring insects in charred remains from the Roman period. Field samples were tested during the excavation of Camelin block, and microscope observation protocols were adapted to entomo-archaeology during anthraco-analysis.
\end{abstract}

Keywords: Roman excavation, Timber, Wood condition, Woodborers, Reference database, Southern France

\section{Introduction}

The stone constructions of the Roman world area wellknown, long investigated field because the remains discovered during archaeological excavations are abundant, and the monuments that are still standing remain as emblems of urbanity and imperial power. The same is not true of wooden construction, whose remains outside wetlands are farless abundant and consequently less studied (Lamouille et al. 2019). The anthracological approach greatly developed in the 1970s. It is based on the study of charcoals from domestic and craft combustion structures (Western, 1963, 1971; Fancelli-Galletti, 1972; Vernet, 1973; Willcox, 1974; Castelletti, 1975). The aim was to document the historical record of vegetation stands, of the local environment, of landscapes, and to reconstruct the morphology of the woodlands from which Roman society took its wood supplies, and thus get a view of their forest management if any. Apart from marine woods and the dendroarchaeological approach, anthracological studies have rarely targeted the carbonized remains of wooden construction, although the wooden structure is very often preserved by fire (Buxó et al., 1996; Chabal, 2012; Liottier, 2019). Moreover, these artifacts constitute additional and complementary information to xylological and anthracological studies.

Our objective was to better evaluate the use of wood in Roman construction and its links with architecture. But in addition to the potential contribution to the understanding of the construction site and the building process, the de- construction processes also need to be documented. Anthraco-entomological analysis (Toriti et al., 2020a, 2020b) characterizes and evaluates the condition of the timber used for construction by identifying the presence of woodborers within the wooden building. Based on this expertise, it is then possible to explain the sustainability of a building or, on the contrary, to understand the mechanisms that have weakened it.

Up to now, entomo-archaeology has been based on the study of insects preserved in archaeological strata (Buckland, 1976; Buckland and Coope, 1991; Moret, 1998; Ponel, 2011), while paleoentomology has been based on other domains than archaeological stratigraphy (Kenward, 1976; Ponel, 2000; Hall et al., 2014; Huchet, 1996, 2017). However, entire insects or even anatomical parts such as elytra or antenna are only exceptionally observed in carbonized remains of wood because the adults fly away once the larval stage is over. On the other hand, traces of their passage through the anatomy of the wood are very frequently observed in the form of wormholes and galleries.

In order to write the history of the construction and deconstruction of buildings, we decided to analyze only the charred woody remains from Roman constructions, with a marked preference for the study of sites in the provinces of Narbonnaise and Cisalpine Gaul. The study area had to be chronologically and geographically circumscribed to build a corpus of sites from comparable periods and implanted in vegetation zones under a marked Mediterranean influence to assess the timber supply channels. We also 
decided to attempt to evaluate the condition of timber. We had to build new analysis tools (an identification key and a reference atlas) to study the xylophagous fauna traces left in timber, and then apply them to the study of the remains of carbonized timber from archaeological sites. The town of Fréjus, where preventive archaeology has been developing for several decades, presented a significant potential for the study of urban carbonized timber, which has been enriched over time.

\section{Study area}

\subsection{Biogeography and vegetation context}

The city of Fréjus is now located in the lower to middle meso-Mediterranean vegetation zone (Ozenda, 1985). Initially dominated by the evergreen oak (Quercus ilex) forest, which is almost absent today because it was largely destroyed, the surrounding woodlands present a degraded facies of pine woods where Aleppo pine, a ubiquitous and pyrophytic species, has acted as a real stop gap along with stone pine and, more sporadically, mesogean pine (Barbero and Loisel, 1974; Ozenda, 1985, 132-133).

Towards the southern coast, between Saint-Raphaël and Saint-Aigulf, scrublands harboring Rhuscotinus and Spartium junceum and grasslands harboring Brachypodium pinnatum dominate. Higher up, the eastern crystalline hills of the Esterrel are occupied by stands of cork oak, myrtle and lentisk, interspersed with maritime pine woods and open formations of cistus (C. monspeliensis and C. ladaniferus), myrtle, narrow-leaved phillyrea and stecade lavender, and maquis-like formations harboring strawberry tree and tree heath (Braun-Blanquet et al., 1952). A thermophilic cork oak forest harboring myrtle and lentisk and a less thermophilic one harboring Genista candicans and Cistus triflorus, interspersed with mesogean pine, cover the western reliefs that dominate the Argens valley. Scrublands harboring Cistus monspeliensis or Lavandula staechas, Myrtus communis and Phillyrea angustifolia, and those harboring Arbutus unedo and Erica arborea provide evidence of the opening of the forest (Barbero and Loisel, 1974).

The upper meso-Mediterranean zone is represented by evergreen oak woods and grasslands harboring Brachypodium ramosum that are all very scarce. They are very quickly intertwined with the supra-Mediterranean zone, which is well developed in the whole northern zone of Fréjus and far beyond. Indeed, the pubescent oak and the Scots pine cap the highest points of the Esterel massif, as on the top of Mont Vinaigre (618 m a.s.I.). They are little developed in the eastern hills dominating the Argens valley, where the chestnut tree is sporadically present on the eastern flank of the Roucas des Lauquières (Barbero and Loisel, 1974). But beyond this, these two species form wide forests (Bargemon, Seillans, Fayence...) above 500 $\mathrm{m}$ above sea level (Ozenda, 1985), with facies becoming more and more collinean and supra-Mediterranean as one goes northwards. Thus, the deciduous oak forests harboring Aleppo pine and mesogean pine and the grasslands harboring Brachypodium pennatum are gradually being re- placed by a deciduous oak forest with Scots pine beyond $15 \mathrm{~km}$ from Fréjus or so. The boxwood formation, the garrigue harboring Buxus sempervirens, Spartium junceum, Coriaria myrtifolia and the grasslands harboring Bromus erectus provide evidence of the opening of the marcescent and supra-Mediterranean oak forests.

The first calcicolous beech woods harboring androsaces of Chaix and presenting decay facies of boxwood at the Glacière pass and in the wood of Malay are located between 1069 and $1397 \mathrm{~m}$ in altitude, and are the southernmost digitation of the Pre-Alps of Grasse-Castellane. They are located $27 \mathrm{~km}$ from Fréjus as the crow flies. The first fir trees are more northernly, at the Collet and Cabannes at the top of the Fil valley (900-1,300 m above sea level). These massifs typically belong to the mountain zone, with Scots pine, beech and fir stands, and even have an asylvatic summit area.

Woodlands harboring white poplars, willows, ash and glutinous alder border the banks of the Argens. sub-Mediterranean and collinean formations where hornbeam can be found along the tributaries, particularly upstream of the Reyran, Riou and Méaulx.

The wooded environment around Fréjus is very rich. Beyond 5-8 km around the city, numerous and diverse forest formations may potentially have supplied the ancient city with timber, given the socio-environmental dynamics in this area during and since antiquity (Dubar, 2004; Chabal, 1991).

\subsection{Archaeological context}

Forum lulii is located on the Mediterranean coast. It was established by Julius Caesar in the middle of the 1st century B.C. Today, as in many other ancient and medieval ports (Lattara, Maguelone, Aigues-Mortes...), clogging and aggradation have caused the shoreline to move 1.5 $\mathrm{km}$ seaward (Dubar 2004, Excoffon, Bonnet 2016). The Archaeology and Heritage Department of Fréjus city was created in 1982 one of the oldest ones in France. It strives to update, record and understand the traces of the town's ancient and medieval past.

In 2013, this service carried out a preventive archaeological excavation of $2,000 \mathrm{~m}^{2}$ on Camelin urban block, located on the south-western flank of the natural hill on which the city is located, under the supervision of P. Excoffon (Figure 1). It cleared the full width of an insula, i.e. $34.23 \mathrm{~m}$, and the two lanes parallel to the main $\mathrm{N}-\mathrm{S}$ axis bordering it. The excavated remains covered more than four centuries of occupation between the end of the 1st century $\mathrm{BC}$ and the 4th century AD (Figure 2) (Excoffon et al., 2013). It was during the diagnosis of the parcel in 2012 (Excoffon, Cordonnier, 2012), that sizeable rubified and burnt down areas were identified. The excavation campaign lasted eight months, and an anthracology specialist, $M$. Toriti, took part to it to carry out the necessary sampling and packaging of the charred woody material on site. 


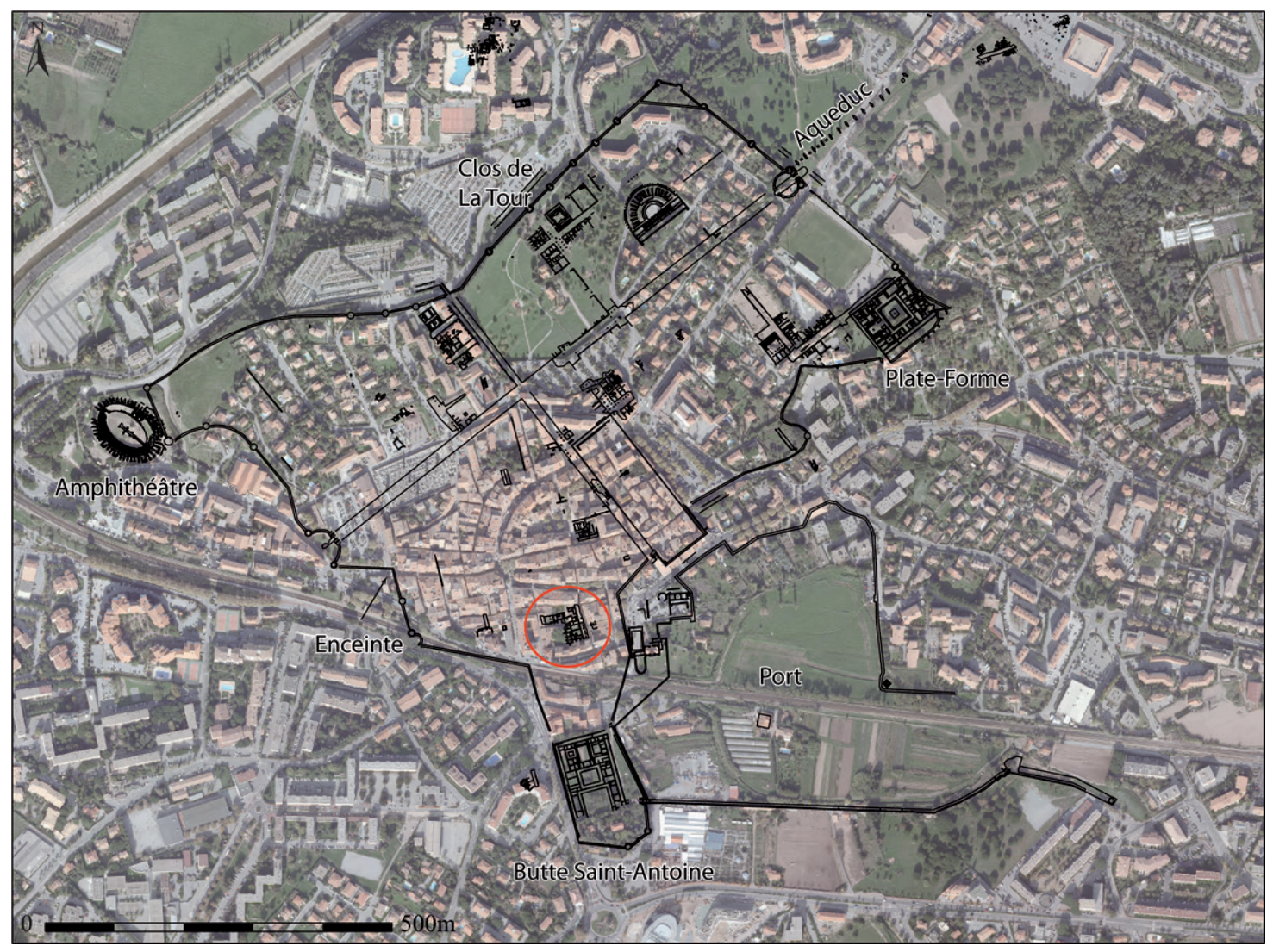

Figure 1. Map of Fréjus city and location of Camelin block (by SAPVF : Archeology and Heritage departement of Fréjus city

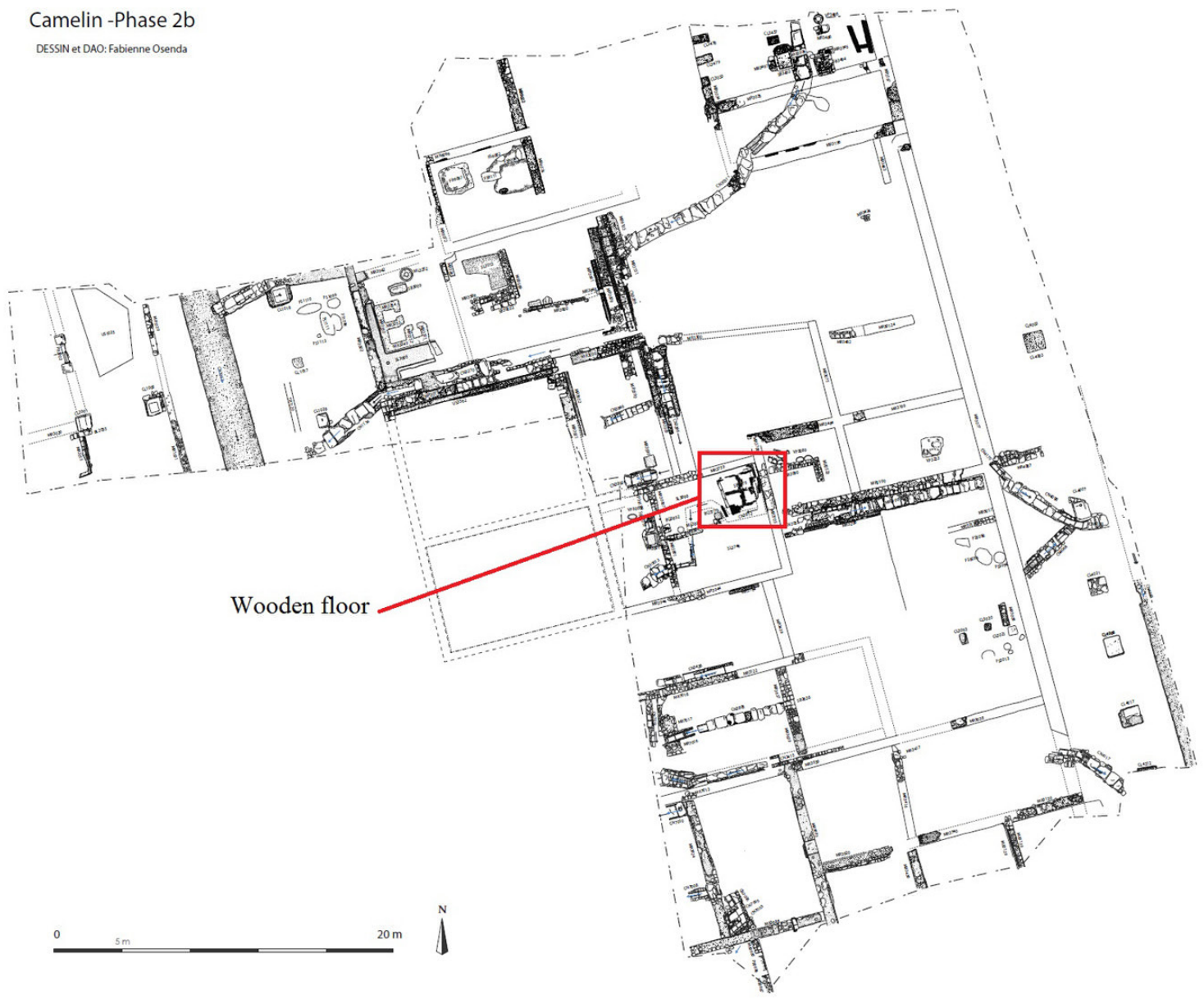

Figure 2. Map of the archeological excavation of Camelin block and location of the wooden carbonized floor (by SAPVF) 


\section{Materials and methods}

\subsection{The wooden floor}

A set of five sandpits and at least 16 boards was discovered dating back to the first half of the 1st century $A D$. The sandpits formed a rectangular frame measuring 2.50 $x 2.10 \mathrm{~m}$. The boards perpendicular to the three east-west joists were mainly in the north-south direction. They were 1 to $3 \mathrm{~cm}$ thick on average at the time of excavation. The structure had few nails, and the main structural elements was slightly disorganized during demolition (Figure 3). Plaster and a partition wall were found above this wooden structure. These collapsed wall and roof elements preserved the wooden structure perfectly after the fire and almost kept it in its original condition. This floor came from a room belonging to a house designated as «house 1A» (Excoffon, Vauxion, 2016). It was dated back to the first half of the 1st century AD, and destroyed before the end of that same century. Situated near a room interpreted as being a kitchen (Excoffon et al., 2016) and probably opening back to an outdoor space, this room, with its elegantly painted wall (Excoffon, Vauxion, 2016), probably corresponded to a reception area. The installation of a drainage channel, a sort of gutter, under the floor also provides evidence of the need to sanitize this surface. Three areas containing fabrics were also located. This floor was used as a test bench for the previously mentioned questions.

\subsection{Sampling and wood identification}

During excavation, each piece of wood was identified, drawn, photographed, measured, and subjected to an accurate and complete architectural and archaeological observation in situ. The five long pieces of wood were entirely removed by section. Each of them was sampled in three sections conditioned in plastic boxes to make laboratory analyses easier. All the pieces of carbonized wood were studied by a classical anthracological approach (Chabal, 1997).

The anthracological analysis of the wooden floor followed a classical method of observation of wood under an optical microscope. Species identification was based on wood anatomy atlases (Greguss, 1955, 1959; Jacquiot, 1955; Jacquiot et al., 1973; Schweingruber, 1990) and on the wood reference collection of the CReAAH CNRS UMR 6566 laboratory. The analysis effort focused on measurements (diameter, length), and the detection of anomalies (bark, knots, departure of branches, compression wood...), especially the identification of dry rot.

\subsection{Sampling and identification of xylo- phagous insects}

Entomo-archaeological analysis consists in a systematic survey and observation of the galleries left by xylophagous insects in each piece of wood, and then measuring their diameter to provide indications on the insects that bore through the wood. For example, the galleries of longhorn beetles, (Cerambycidae family), are recognizable by their oval shape and a fairly large size, greater than 3 $\mathrm{mm}$ in diameter. But gallery size is not a sufficient criterion to identify the pest involved because it depends on larval development. Therefore, the diagnosis more specifically focused on the observation of faecal pellets (larval excrement): size, appearance, shape, texture. The faecal pellet is indeed a discriminating element, as each xylophagous insect secretes their own pellets, which differ in size, shape and composition from those of other xylophagous insects. Faecal pellets were sampled by patting the wood and scratching the edges of the inner galleries with a pin.

To better characterize the presence of archaeological woodborers based on their excrement, a reference collection based on the galleries and faecal pellets of living insects bred in the CICRP (Interdisciplinary Center for the Conservation and Restoration of Heritage) laboratory in Marseille was elaborated. A specific determination key in the form of an illustrated atlas based on an anatomical description is being finalized (Toriti, 2018). The methodology used to build this identification key was a classical approach to morphometry: the faecal pellets of each $x y$ lophagous species were collected from the collections of living insects of the CICRP and then systematically measured. Groups of statistically different sizes and morphologies were characterized to distinguish not only families but also genera. This was the case within the Ptinidae family (Fohrer et al., 2017).

The interweaving of all these observations made it possible to identify the woodborers. But the precision of these identifications ranged from the family level to the genus and species levels: cerambycids gather 250 species (Berger, 2012) that cannot be discriminated to the present day; on the other hand, the most common insects among Ptinids are determined at the species level (Anobium punctatum (De Geer, 1774), Nicobium castaneum (Olivier, 1790), Oligomerus ptilinoides (Wollaston, 1854)) (CTBA, 1996; Fohrer et al., 2017; Toriti, 2018).

Sampling archaeological artefacts or ecofacts determines the quality and reliability of the results of the study. Therefore, special attention was paid to the sampling of wood material throughout excavation.

\section{Results}

\subsection{Anthracological results}

A total of 1,572 charcoals from the floor was analyzed (Figures 4 and 5). Beech (Fagus) came first with 34\%, i.e. 535 charcoals identified in all wooden elements, corresponding to the two preserved sandpits ( $\mathrm{CH} 20$ and 27), two of the three joists $(\mathrm{CH} 22-23)$ as well as more scattered elements, probably belonging to the sandpits or joists $(\mathrm{CH} 4,6,14,15$ and 17), which came off when the walls and roof collapsed. Aleppo pine/stone pine (Pinus halepensis/P. pinea) was the second most represented taxon with $26.59 \%$, to which must be added Aleppo pine (Pinus halepensis) per se at $14.06 \%$. These charcoals corresponded to remains of boards from which a thin $(2-3 \mathrm{~cm})$ layer was preserved $(\mathrm{CH} \mathrm{1,} \mathrm{2,} \mathrm{3,} \mathrm{5,} \mathrm{7,} \mathrm{8,} \mathrm{10,} \mathrm{11,} \mathrm{12,} \mathrm{13,}$ 


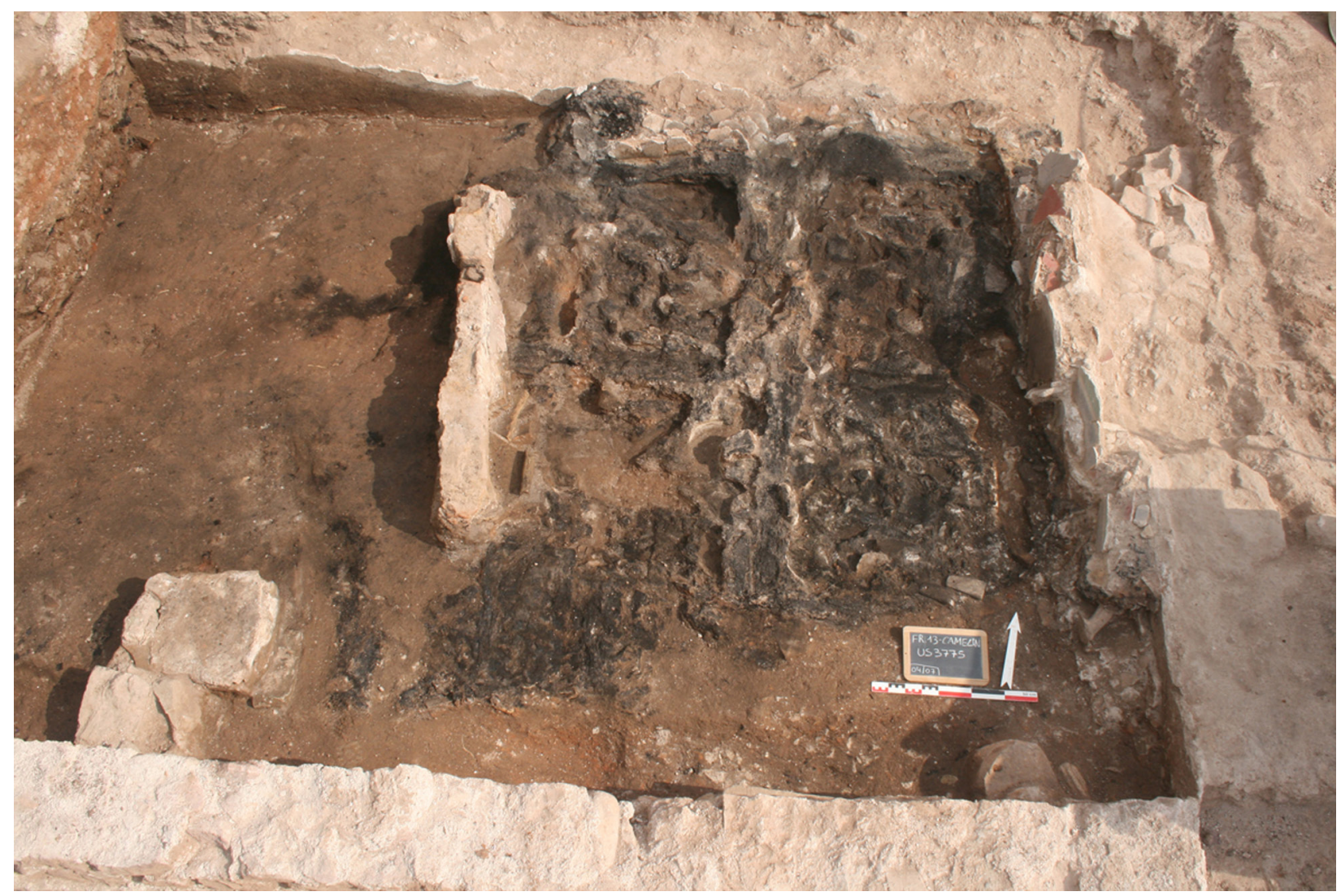

Figure 3. View of the floor at the time of its discovery, photography by SAPVF.

US 3769

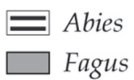

- Pinus halepensis/P. pinea

$\triangle \Delta$ Pinus type sylvestris

$\square$ Quercus

- Nail

$\star$ Carbonized fabric

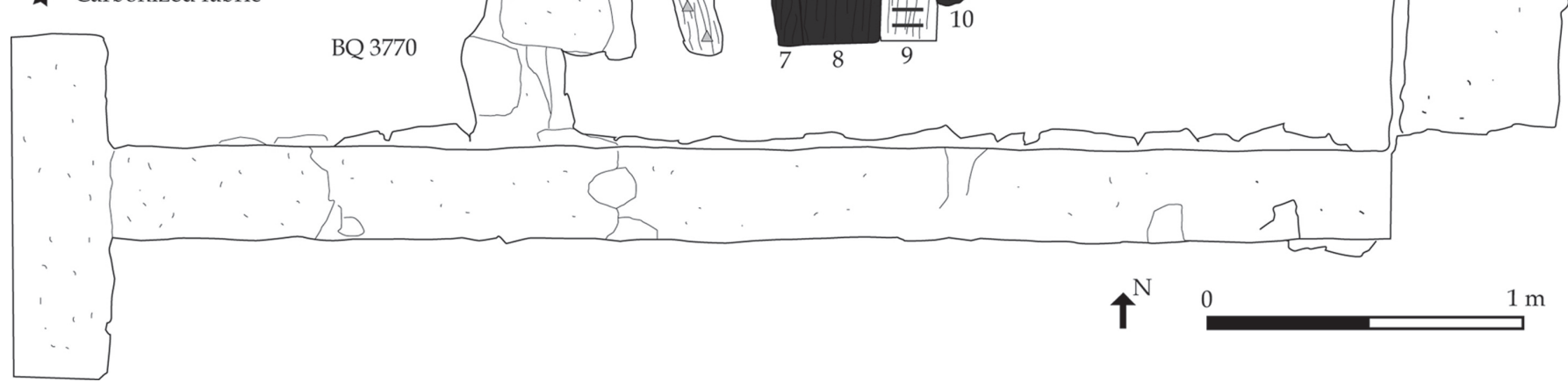

Figure 4. Distribution of woody floor species, CAD, M.Toriti, according to SAPVF. 
18, 24, 25 and 26). With $11.96 \%$ of presence, fir (Abies) appeared distinctly in one joist $(\mathrm{CH} 21)$ and one plank $(\mathrm{CH}$ 9). Plank 19 was exclusively made of Scots pine (Pinus sylvestris type: $1.9 \%$ ). Finally, deciduous oak (Quercus: 0.25\%; Quercus D. F.: 0.25\%) was used for piece No 16 .

Compression wood was observed on all coniferous pieces: $63 \%$ of Aleppo pine/stone pine fragments exhibited compression wood, including $6.7 \%$ corresponding to moderate to strong compression; $26.7 \%$ of the Scots pine fragments and $37.8 \%$ of the fir fragments were affected by weak compression. The vertical tracheids, visible mainly in radial longitudinal section, showed helical cracking of the walls giving them an airy twisted appearance (low compression) except for parts 2, 8 and 25, which had a tighter appearance (moderate compression).

On the northern part of the floor where the carbonized woody remains were next to the remains of fabric and bread, the analysis revealed various other species such as cork oak or evergreen oak (Quercus suber: 3.43\%; Quercus sempervirens: $0.64 \%$ ), alder (Alnus: $3.12 \%$ and cf. Alnus: $0.19 \%$ ), ash (Fraxinus: $0.51 \%$ ), maple (Acer: $0.45 \%)$, and boxwood (Buxus: $0.13 \%$ ). Bark was still visible on some of these fragments, and others were very small in size. This supports the hypothesis that they were part of to sets of small woods, such as bundles, stored on the floor at the time of the fire.

\subsection{Entomological results}

A total of 753 galleries was observed on 553 charcoals, corresponding to $35.22 \%$ of the whole structure. The iden- tified traces of infestation were of the beetle type: Anobium punctatum (Figure 6; Table 1) at 37.99\%, Oligomerus cf. ptilinoides at $1.59 \%$, and Ptinidae at $41.43 \%$. A significant number of galleries-18.99\%-, remained undetermined because of the excessive degradation of the pellets (melted, agglomerated) due to carbonization.

Only $\mathrm{CH} 16$ (oak) and $\mathrm{CH} 19$ (Scots pine type) showed no evidence of woodworm infestation. On the other hand, the other 25 carbonized elements contained two to several dozen galleries; $\mathrm{CH} 27$ was the most impacted item with 104 galleries. This proportion corresponds to an infestation rate (number of infested charcoals over the number of observed charcoals) of nearly $74 \%$.

Infestation was greatest in the eastern part and in the center of the structure. Elements in the eastern part of the structure $(\mathrm{CH} 1,2,3,4,5,6,22,24$ and 27) kept the stigma of a dry rot fungus (Figure 7 ).

Among all the data collected on infestations, beech, which corresponded to the larger sizes as in $\mathrm{CH} 20$, was the species with the highest infestation rate $(58 \%)$, followed by Aleppo pine/stone pine $(28 \%)$, and fir $(11 \%)$. The remaining 3\% concerned all infestations of species previously considered as residual and potentially of wood stored in the room (alder, maple, boxwood, etc.).

An irregularly shaped gallery on piece $\mathrm{CH} 24$ did not provide any pellet and was therefore not determined. On the other hand, two potential fumitory (Fumaria spp.) seeds were found inside the gallery. Their presence suggests that ants might have stored these seeds in the galleries.

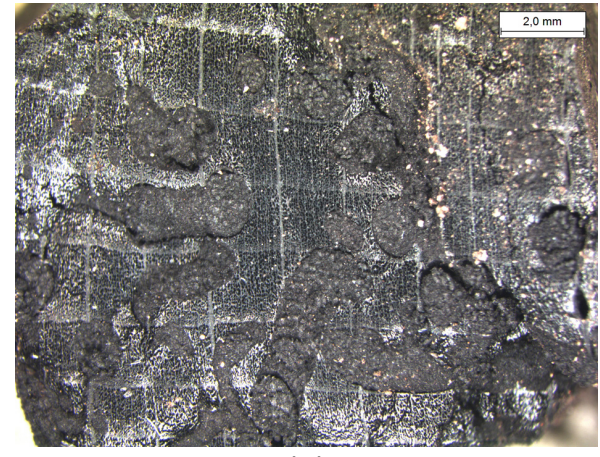

(a)

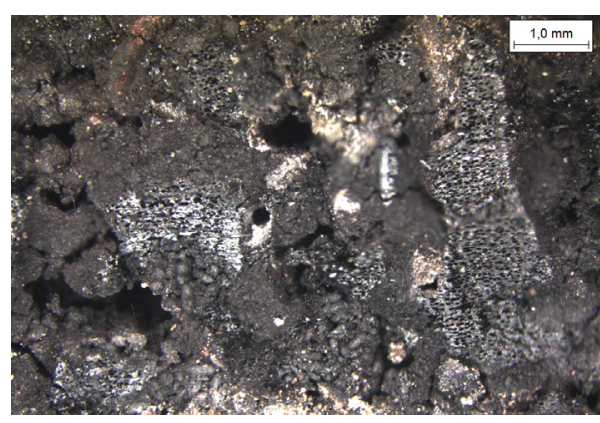

(d)

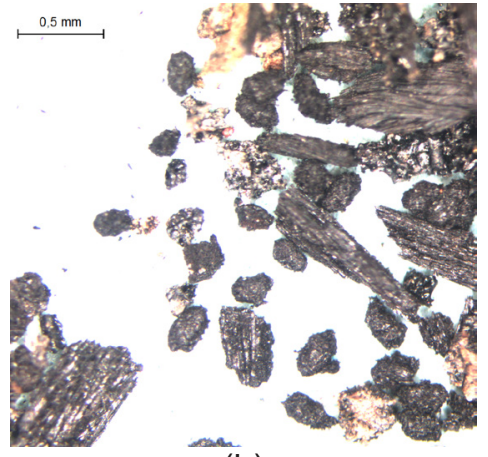

(b)

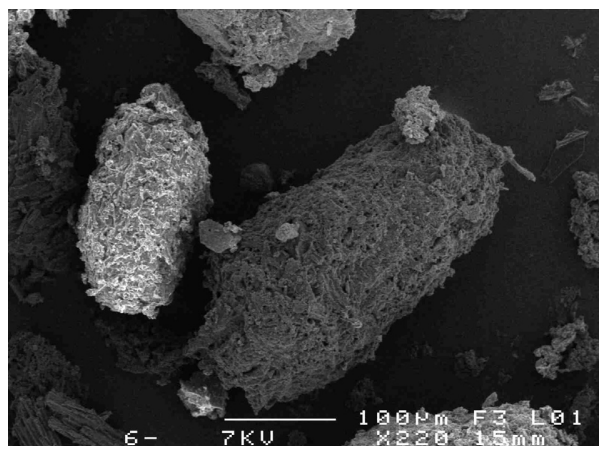

(c)

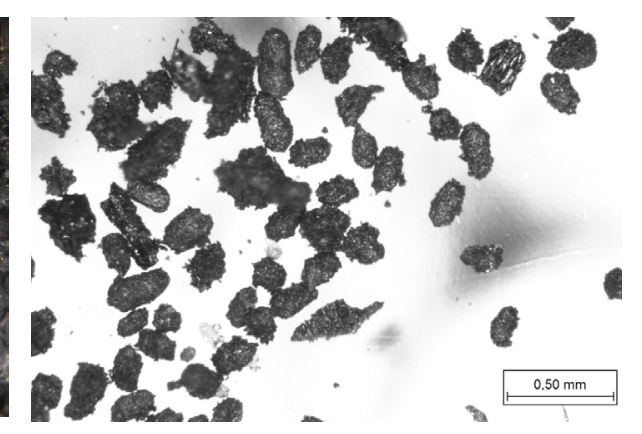

(e)

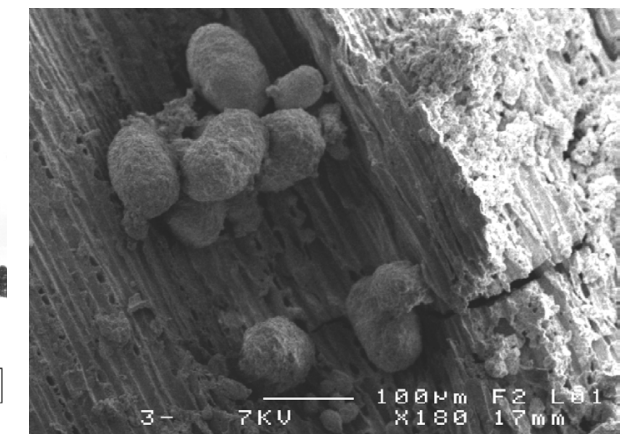

(f)

Figure 5. Example of a beech wood sample infested with numerous galleries A.punctatum, M. Toriti. b. Archaeological faecal pellets of Anobium, M. Toriti. c. Carbonized A. punctatum faecal pellets from the floor, CMEBA-Scanmat. d. Example of a beech wood sample infested by Oligomerus, M. Toriti. e. Archaeological faecal pellets of Oligomerus, M. Toriti. f. Carbonized Oligomerus faecal pellets from the floor, CMEBA-Scanmat. 


\begin{tabular}{|c|c|c|c|c|c|c|}
\hline Wood piece & Dominated taxa & $\begin{array}{l}\text { Other taxa (bun- } \\
\text { dles with bark) }\end{array}$ & $\begin{array}{l}\mathrm{Nb} \text { of analyzed } \\
\text { fragments }\end{array}$ & $\begin{array}{c}\text { Structure ele- } \\
\text { ment }\end{array}$ & Insect traces & $\begin{array}{c}\text { Cube rot } \\
\text { traces }\end{array}$ \\
\hline $\mathrm{CH} 1$ & Pinus halepensis & Alnus & 60 & Board & $x$ & $x$ \\
\hline $\mathrm{CH} 2$ & Pinus halepensis & - & 60 & Board & $x$ & $x$ \\
\hline $\mathrm{CH} 3$ & Pinus halepensis & - & 30 & Board & $x$ & $x$ \\
\hline $\mathrm{CH} 4$ & Fagus & Fraxinus & 100 & Plate element & $x$ & $x$ \\
\hline $\mathrm{CH} 5$ & Pinus halepensis & - & 40 & Board & $x$ & $x$ \\
\hline $\mathrm{CH} 6$ & Fagus & - & 40 & Plate element & $x$ & $x$ \\
\hline $\mathrm{CH} 7$ & Pinus halepensis & - & 30 & Board & $x$ & - \\
\hline $\mathrm{CH} 8$ & Pinus halepensis & - & 60 & Board & $x$ & - \\
\hline $\mathrm{CH} 9$ & Abies & - & 60 & Board & $x$ & - \\
\hline $\mathrm{CH} 10$ & Pinus halepensis & - & 30 & Board & $x$ & $x$ \\
\hline $\mathrm{CH} 11$ & Pinus halepensis & - & 30 & Board & $x$ & - \\
\hline $\mathrm{CH} 12$ & Pinus halepensis & Acer, Alnus & 40 & Board & $x$ & - \\
\hline $\mathrm{CH} 13$ & Pinus halepensis & - & 27 & Board & $x$ & - \\
\hline $\mathrm{CH} 14$ & Fagus & - & 50 & Plate element & $x$ & - \\
\hline $\mathrm{CH} 15$ & Fagus & Fraxinus & 60 & Plate element & $x$ & - \\
\hline $\mathrm{CH} 16$ & Quercus & - & 53 & Plate element & - & - \\
\hline $\mathrm{CH} 17$ & Fagus & - & 100 & Plate element & $x$ & - \\
\hline $\mathrm{CH} 18$ & Pinus halepensis & - & 23 & Board & $x$ & - \\
\hline $\mathrm{CH} 19$ & Pinus type sylvestris & - & 30 & Joist element & - & - \\
\hline $\mathrm{CH} 20$ & Fagus & $\begin{array}{c}\text { Bruxus, Quercus } \\
\text { suber }\end{array}$ & 120 & Plate & $x$ & - \\
\hline $\mathrm{CH} 21$ & Abies & Quercus suber & 100 & Joist & $x$ & - \\
\hline $\mathrm{CH} 22$ & Fagus & Alnus & 100 & Joist & $x$ & $x$ \\
\hline $\mathrm{CH} 23$ & Fagus & - & 59 & Joist & $x$ & - \\
\hline $\mathrm{CH} 24$ & Pinus halepensis & - & 60 & Board & $x$ & - \\
\hline $\mathrm{CH} 25$ & Pinus halepensis & - & 30 & Board & $x$ & - \\
\hline $\mathrm{CH} 26$ & Pinus halepensis & - & 40 & Board & $x$ & - \\
\hline $\mathrm{CH} 27$ & Fagus & Alnus, Quercus & 100 & Plate & $x$ & $x$ \\
\hline
\end{tabular}

Table 1. Anthracological identification and characterization of woody floor species.

\begin{tabular}{|c|c|c|c|c|c|c|}
\hline Wood piece & Anobium punctatum & $\begin{array}{l}\text { Oligomerus ptili- } \\
\text { noïdes }\end{array}$ & Ptinidae & Undetermined & $\begin{array}{l}\text { Total galle- } \\
\text { ries }\end{array}$ & $\begin{array}{c}\text { Proportion of the } \\
\text { infestation (\%) }\end{array}$ \\
\hline $\mathrm{CH} 1$ & 1 & - & 9 & 5 & 15 & 21,7 \\
\hline $\mathrm{CH} 2$ & 3 & - & 5 & 6 & 14 & 20 \\
\hline $\mathrm{CH} 3$ & 4 & - & 13 & - & 17 & 50 \\
\hline $\mathrm{CH} 4$ & 12 & - & 36 & 10 & 58 & 52 \\
\hline $\mathrm{CH} 5$ & 2 & - & 5 & 1 & 8 & 20 \\
\hline $\mathrm{CH} 6$ & 2 & - & 2 & 1 & 5 & 10 \\
\hline $\mathrm{CH} 7$ & 1 & - & 2 & 3 & 4 & 13,3 \\
\hline $\mathrm{CH} 8$ & 3 & - & 2 & - & 5 & 8,3 \\
\hline $\mathrm{CH} 9$ & 9 & - & 7 & 3 & 19 & 18 \\
\hline $\mathrm{CH} 10$ & - & - & 8 & 2 & 10 & 30 \\
\hline $\mathrm{CH} 11$ & 1 & - & - & 1 & 2 & 6,7 \\
\hline $\mathrm{CH} 12$ & 3 & - & - & - & 3 & 7,5 \\
\hline $\mathrm{CH} 13$ & 3 & - & 1 & - & 4 & 14,8 \\
\hline $\mathrm{CH} 14$ & 4 & - & - & 3 & 7 & 12 \\
\hline $\mathrm{CH} 15$ & 20 & - & 7 & 7 & 34 & 50 \\
\hline $\mathrm{CH} 16$ & - & - & - & - & - & - \\
\hline $\mathrm{CH} 17$ & 53 & - & 5 & 1 & 59 & 55 \\
\hline $\mathrm{CH} 18$ & 12 & - & 16 & 10 & 38 & 52,2 \\
\hline $\mathrm{CH} 19$ & - & - & - & - & - & - \\
\hline $\mathrm{CH} 20$ & 33 & 12 & 15 & 3 & 63 & 45,8 \\
\hline $\mathrm{CH} 21$ & 1 & - & 46 & 1 & 48 & 28 \\
\hline $\mathrm{CH} 22$ & 20 & - & 34 & 6 & 60 & 44 \\
\hline $\mathrm{CH} 23$ & 34 & - & 54 & - & 88 & 21,3 \\
\hline $\mathrm{CH} 24$ & 24 & - & 23 & 9 & 56 & 78,3 \\
\hline $\mathrm{CH} 25$ & 7 & - & 1 & 2 & 10 & 33,3 \\
\hline $\mathrm{CH} 26$ & 14 & - & 7 & 1 & 22 & 50 \\
\hline $\mathrm{CH} 27$ & 21 & - & 16 & 68 & 104 & 74 \\
\hline TOTAL & 286 & 12 & 312 & 143 & 753 & 35,22 \\
\hline$\%$ & 37,99 & 1,6 & 41,43 & 18,99 & 100 & - \\
\hline
\end{tabular}

Table 2. Identification of insects according to the floor room. 


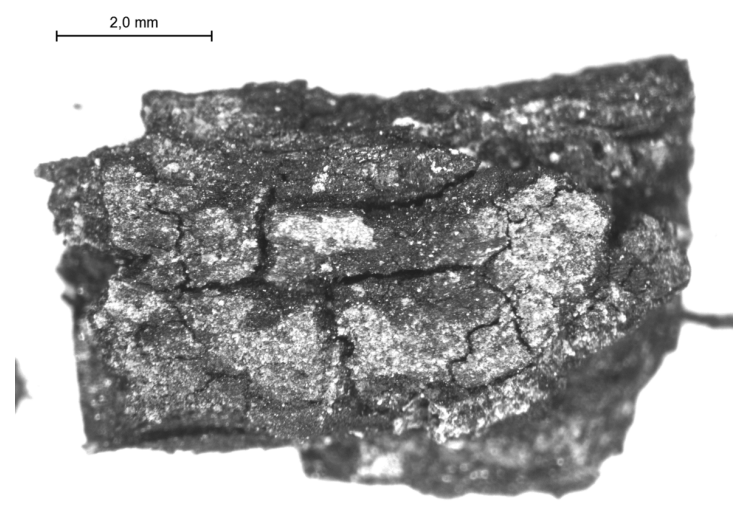

(a)

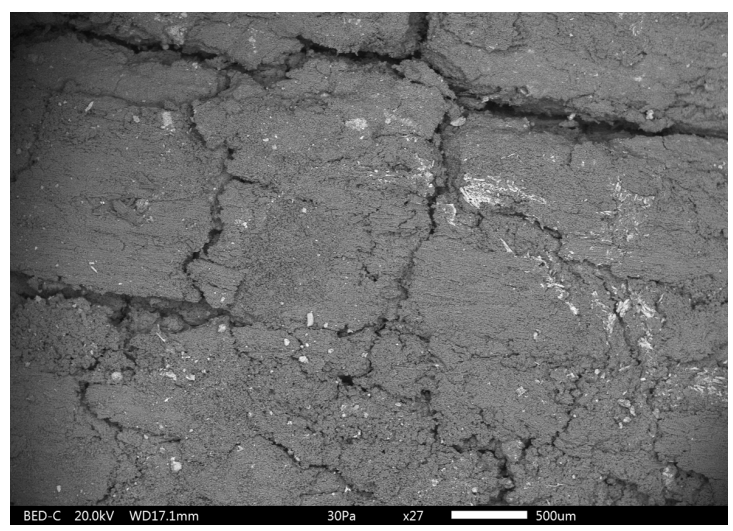

(c)

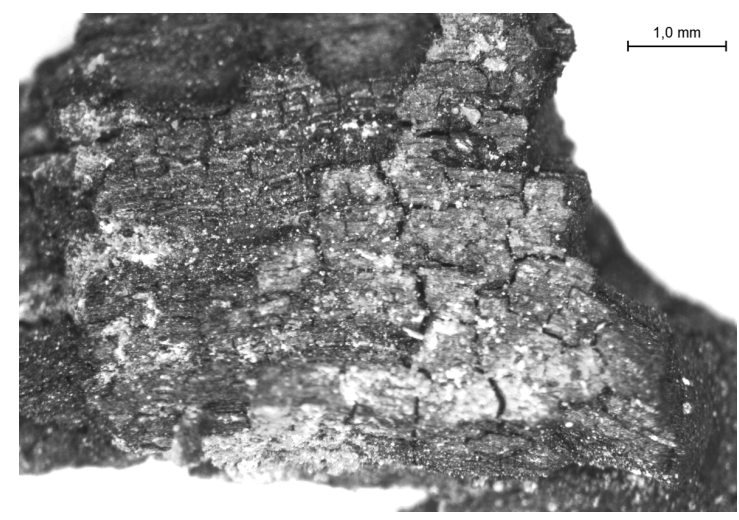

(b)

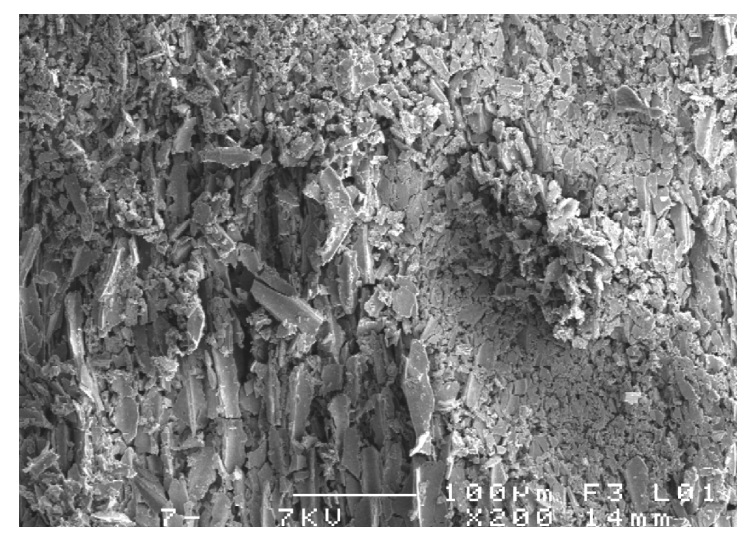

(d)

Figure 6. Cubic-rot on carbonized beech ( $\mathrm{CH} 27$ ), M. Toriti. b. Cubic-rot on carbonized beech (CH 4), M. Toriti. c. General view of cubic-rot, CMEBA-Scanmat. d. Detail of damage caused by cubic-rot on wood, CMEBA-Scanmat.

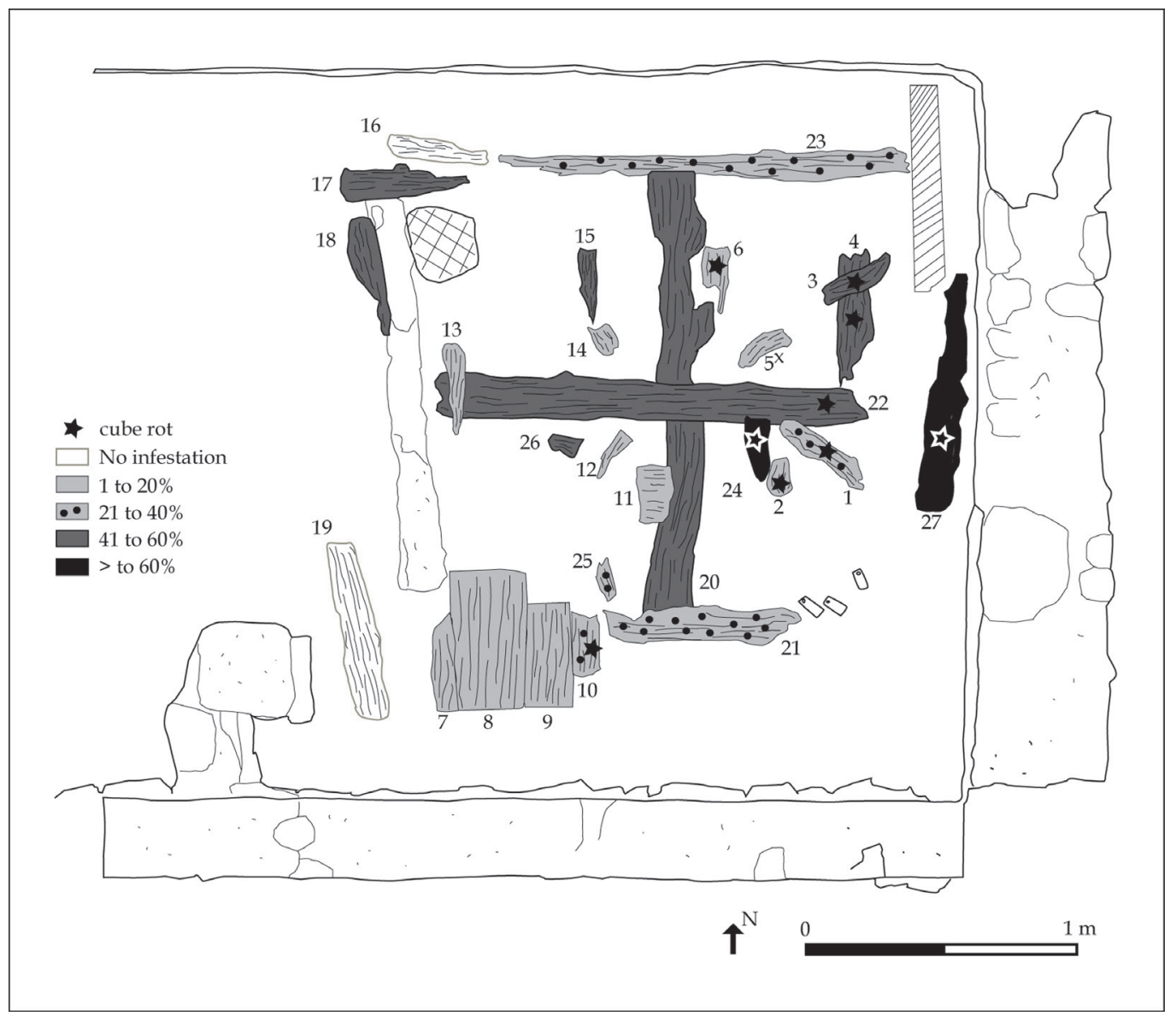

Figure 7. Distribution of A. punctatum galleries, CAD, M. Toriti. 


\section{Discussion}

\subsection{Roman Timber: Supply Area and En- vironmental Availability}

During the first half of the 1st century A.D., the construction of the insula discovered in Camelin block required a supply of building materials for its various buildings, i.e. stone, wood, but also clay, since many elements of unbacked clay architecture (bricks) were preserved thanks to the fire. The city, founded more than one century before, was a mineral universe where woodlands had no longer their place; consequently, the timber used for construction was exogenous to the city. The question that now arises is whether this timber supply was proximate or distant, and in turn what degree of economic and commercial, and even political influence Fréjus had on its territory and its proximate or more distant environment. Taking into account the socio-environmental dynamics known in this geographical area at the scale of eastern Provence during ancient times (Borréani et al., 1992; Dubar et al., 2004, 2011; Chabal, 2003,2014 ), the biogeographical limits of the vegetation zones have not significantly changed since antiquity: it is therefore possible to approach the question of provenance through this lens.

The species identified in the manufacturing of the floor were of the Pinus halepensis/P. pinea, Pinus sylvestris types, Quercus deciduous type, Fagus and Abies. The Aleppo pine and stone pine woods currently occupy the hills bordering the Argens river and extend up into the Maures and Estérel massifs. The builders of the insula had barely $5 \mathrm{~km}$ to travel to reach these hills. According to the Camargue and Lattois models (Puertas, 1998; Chabal, 1991, 1997, 2019), the stone pine can also cover the coastal areas, which were even closer at that time since the shoreline was closer by $1.5 \mathrm{~km}$ (Dubar, 2004; Excoffon and Bonnet 2016). Palynological data from the Argens Valley showed an increase in pine and tree heather pollen rates $(30 \%$ to $60 \%$ in some diagrams) towards $3000 \mathrm{BP}$, which indicates forest opening (Dubar et al., 2004, 2011). Although pine pollen cannot be discriminated at the species level, its association with tree heather, whose pollen diffuses little, and the joint evolution of the two curves, which is reminiscent of the Ericetosum association (Braun-Blanquet, 1936; Braun-Blanquet et al., 1952), argues in favor of Pinus halepensis and thus of a very local pollen composition. These data validate the hypothesis of a first immediate, very local supply area, less than 4 - $5 \mathrm{~km}$ around Forum Iulii.

The second supply area was further away. In fact, the marcescent oak fully develops in the upper meso-Mediterranean and supra-Mediterranean zones, and the Scots pine in the supra-Mediterranean and mountainous vegetation areas. More rustic and less thermophilic than Quercus pubescens, it can infiltrate the lower part of the pubescent oak forest and even go down to 200 m (Quézel and Médail 2003). It only becomes dominant in the upper parts of the series as in the Maures and Esterrel. The pubescent oak is more calcicolous and therefore very little present on the siliceous soils of the Maures and Esterel, and prefers the valleys with deeper and more humid soils (Quézel and
Médail 2003). Palynological and anthracological data on this point are of no help. Based on the distribution of a few decades ago (Barbero and Loizel, 1974), the potential supply area would have been more than ten kilometers away as the crow flies, drawing a second probable supply area around Fréjus.

The characterization of beech and fir refers to montane ecosystems and to altitudes above $800-1,000 \mathrm{~m}$. The first beech woods are now $27 \mathrm{~km}$ from Fréjus as the crow flies, and the first fir woods $35 \mathrm{~km}$ away, near the aqueduct that supplied water to the town of Fréjus during the Roman period. This situation would draw a third, very distant supply area -between 25 and $35 \mathrm{~km}$-, which raises the question of the means of transport (water, cart...). But another hypothesis seems much more certain. Until around 3000 BP, mesophilic taxa (Quercus D. F., Corylus, Fagus) dominated the pollen spectra of the Argens valley cores and strongly decreased afterwards (Dubar et al., 2004, 2011). According to Bui-Thi-Mai, beech and especially fir forests are established in the neighboring massifs of the Argens basin following a vegetation dynamic well characterized in Provence (Beaulieu, 1977; Triat-Laval, 1978; Nichol-Pichard, 1987; Violino et al., 1993; Nicol-Pichard and Dubar, 1998; Andrieu-Ponel et al., 2000a, 2000b; Delhon and Thiébault, 2005) and in Languedoc (Planchais, 1982, 1987; Durand and Vernet, 1987; Durand 1992, Chabal, 1997, 2012; Britton et al., 2007; Liottier, 2019). As fir pollen is poorly dispersive, its presence implies the presence of producing trees in the close vicinity. At Fréjus, rare identifications of fir have been noted in the anthracological and palynological diagrams from the Villa Romana site (Bouby et al., 2011, 225; Guillon, 2011, 241) as in Augustonemetum (Clermont-Ferrand) surrounding (Cabanis, Marguerie, 2013). In addition, numerous antique and medieval unpublished anthracological data (Cenzon, 2014; Venot-Tisserand, 2016), weakly characterize beech, or even fir, in archaeological sites located lower than their usual biogeographical limits in Provence. L. Chabal (2012) showed that the current distribution of fir could not be transposed to the ancient period and, based on ecological models, postulated for its presence at low altitude in Languedoc. P. Quézel and F. Médail (2003) indicate that it can infiltrate mixed oak forests. In Languedoc, beech definitively disappeared from the low-altitude Mediterranean complex during the Middle Ages (Durand, 1992, 1998). We can therefore envisage that beech and fir tree formations still existed in the valleys of the Argens and its tributaries during the ancient period thanks to privileged edaphic conditions. This very mesophilic third timber supply area would have been less than 25-35 km away from Fréjus, and closer to the second area that developed more than $10 \mathrm{~km}$ away from Fréjus. Even if the distance was short, the question of the transport of pubescent oak, Scots pine, fir and beech timber remains entirely open.

The environmental availability determined the localization of Fréjus timber supply areas. The analysis of a floor showed that during the 1 st century $A D$, a period of full economic and political development of the city, these areas delineated a proximate or local territory within a radius of no more than $25-30 \mathrm{~km}$ around the city. As in Lattara, in 
Augustonemetum (Clermont-Ferrand) or in Roman cities from Belgica Gaul (Bernard, 2003; Cabanis, Marguerie, 2013; Blondel, Girardclos, 2018; Liottier, 2019) or even in Herculaneum (Moser et al., 2018), they did not reveal inter-regional or international trade over very long distances as recent dendrochronological analysis of documents did for Rome (Bernabei et al., 2019). The builders chose the closest possible available natural resources, whose location and properties they knew perfectly well.

\subsection{Roman timber: between technical choices and mechanical properties}

The technical and mechanical properties required from timber are another key to reading the data from the floor of Camelin block. It was therefore necessary to investigate them through the lens of the relevance of the chosen wood in relation to its morphological, mechanical and physical properties with a view to a precise use of the piece of wood (in this case the slats, joists and sandpits supporting the floor).

As regards Gymnosperms, the regular characterization of compression wood (63\% in total) means that the subjects grew under sufficiently difficult conditions for these stresses to be reflected in the anatomy of the wood. Given the geographical context, these were probably either trees rooted on fairly gentle slopes that corresponded well to the mounds and reliefs surrounding Fréjus since compression was generally moderate, or the lower part of large branches where growth had to be rebalanced. Today, compression wood is considered as a defect by the industry because of the loss of elasticity and tensile strength, which makes it more difficult to work, especially with a saw, and unsuitable for use in logs and beams, a fortiori in parquetry, because the knots stand out on the surface of the boards. However, it is 10 to $40 \%$ denser than normal wood and, as its name suggests, is more resistant to compression. The craftsmen of Fréjus clearly did not stop at these difficulties visible to the naked eye (color, shape, decentring pith...): they did not hesitate to cut coniferous trees, whether from Mediterranean or mountain areas, into planks; it can be assumed that this work was not done with a saw. Usually, these species were commonly used during protohistory and antiquity as beam timber or marine wood because they had a long span and straight trunks (Küster, 1993; Veal, 2017: 328-329; Moser et al., 2018; Liottier, 2019: 117, 153). But they also made good shelf and flooring wood or were used to make little furniture such as buckets, chests... (Bernard, 2003). Fir was especially used to make boards (floors or roofs) as early as protohistory, especially for shelving and mezzanines, and was probably selected for this purpose (Bernard, 2003; Cabanis, Marguerie, 2013; Veal, 2017, 340; Blondel, Girardclos, 2018; Liottier, 2019: 192, 202-207, 256, 268-281). This was also the case in Fréjus. Because of this specific use, fir timber would have been cut on site in mobile workshops to avoid the long-distance transport of heavy logs (Bernard, 2003; Blondel, Girardclos, 2018; Liottier, 2019).

The construction of the structure combined coniferous and deciduous trees. Beech was the most frequently used spe- cies in the structure, especially for sandpits, as it is a longspanned, hard, dense wood, well suited for the frames. L. Liottier (2019: 204, 226) characterized this species for the manufacturing of door frames, but not for doors themselves; in Fréjus, similarly, the structure was made of beech, but the planks were not. Oak of the pubescent type, very hard, resistant, able to provide long spans when treated in stand, was used for a single piece of sandpit (CH 16). The set revealed a combination of complementary species combining hardwoods to strengthen its resistance and lighter ones. This phenomenon was common in the manufacturing of doors (Chabal, 2014).

The craftsmen of Fréjus were able to combine the availability of species found in their environment and the qualities required to build the floor: sometimes solidity and density for the structure, sometimes lightness and the ability to be cut into planks.

\subsection{Life and Death of a Wooden Construc-} tion: The Example of a Floor

Anthraco-entomological analysis only revealed the presence of xylophagous beetles belonging to the Ptinidae family in the floor of Camelin block. However, $35.2 \%$ of the wood used to build the structure was infested, which is a very high percentage compared to other studies of this type on timber (Toriti, 2018; Toriti et al., 2020a, 2020b). This underlines an ongoing process of weakening of the wood of this structure brought to a halt by the fire. The details of the stratigraphy and the good conservation of the wood floor helped us to characterize this process.

Ptinidae are considered as sinanthropic and specialized in attacking dry wood, so their presence in worked wood is not surprising. The furniture beetle is ubiquitous in all woodwork, whether used for architecture or furniture (Lepesme, 1944; Delobel, Tran, 1993; Laclos, Büche, 2008). The genus Anobium was previously identified in the ancient site of the Villa Romana in Fréjus (Ponel, 2011, 254). Nevertheless, infestation can be favored by prior weakening of the structure, as in the present case: some time after the construction of the room, the gutter located under the sandpit to evacuate the general humidity of the room was actually a regular vector of humidification of the floor wood. As a consequence, a dry-rot type fungus developed, which was clearly observed during the anthraco-entomological diagnosis. The presence of this fungus accentuated the attractiveness of the wood for xylophagous insects, especially Anobium punctatum in sapwood (Bletchy, 1953), because it made it more digestible. Subsequently, the fungus gradually spread to the boards of the eastern part of the structure. The wood was humidified by the presence of the gutter, which favored the development of the fungus counter to its initial draining function, and this was the initial cause of the generalized infestation of the floor by the woodworm. The high concentration of galleries in the boards ( $\mathrm{CH} 27,24,1$ and 22; Figure 7) of the eastern part of the structure, also contaminated by the fungus, supports this hypothesis.

Common furniture beetles damage both hardwood and 
softwood without any distinction between the two. Nevertheless, they infested proportionally more beech sandpits and joists in this floor than they did for pine boards, which they probably only attacked secondarily. Over the generations, woodborers probably left the lower wooden pieces which had grown less attractive because they had already been eaten -to turn to the upper ones. Given the minimum number of galleries recorded, $A$. punctatum infested the floor over at least two generations, and each generation lived in the wood for one to four years depending on the immediate environmental conditions in and around the building. Infestation therefore began at least two to eight years back. This raises questions about the perception of the phenomenon by the users of the building, and of this room in particular, since the flight holes of the common furniture beetle can be seen by uninformed eyes. This remark is all the more interesting as the room where the floor was laid was an important room intended for reception within a refined house of this insula.

The question of the oak piece ( $\mathrm{CH} 16)$, located between the beech sandpit $\mathrm{CH} 23$ and the beech piece $\mathrm{CH}$ 17, remains unanswered. Although all three pieces appear to belong to a continuum, the switch from heavily infested beech to completely healthy oak and back to infested beech raises the hypothesis of the repair of a beam of the floor that may have been too damaged by the infestation.

Anthraco-entomological analysis identified two species of Ptinidae, i.e. A. punctatum and O. cf. ptilinoides, which can coexist without any real competition. Timber colonization by two different insect species reinforces the idea of very attractive conditions for woodborers in this structure and suggests that generations may have followed one another quite rapidly. By characterizing two species from the same family, we can better measure the full impact of their attacks on the mechanical properties of the wood. Indeed, O. cf. ptilinoides larvae dig slightly larger galleries than $A$. punctatum larvae do, and cause more serious damage to the structure. Only the central $\mathrm{CH} 20$ sandpit of the wooden structure kept traces of $O$. cf. ptilinoides activity. This may have been the beginning of infestation by a new species (Oligomerus), which failed due to the general fire of the building. The same may be true for the potential ant tracks in wood piece number 24 , which were deposited shortly before the fire, but ants had no opportunity to colonize other parts of the structure.

\section{Conclusion}

The innovative use of anthraco-entomology opens up a new field of research interweaving the historical record of construction and that of pests. In the case of the excavation of Camelin block in Fréjus, it helped to approximate the location of timber supply areas and to reconstruct the entire implementation and destruction of the flooring of one of the houses of this insula.

The specific characterization of the wood used in the structure highlighted three potential supply areas. The first was the closest and most proximate one, less than 4-5 $\mathrm{km}$ around Fréjus: this was the area where the loggers, carpenters and joiners cut Aleppo pine/stone pine mainly into boards; the second one was more than $10 \mathrm{~km}$ away and concerned afforestation of the Scot pine type and marcescent oak type. The third one was a priori about $30 \mathrm{~km}$ away, but the beech and fir forests were likely closer to the ancient city than their current biogeographical distribution seems to indicate, so that this last circle was finally quite similar to the previous one. The woodcutters sought for long, straight, resistant timber to obtain good wood for beams (beech and pubescent oak) and floors (fir and pine). This is a first approach to the practices and uses of timber and the links that wood craftsmen had with their ligneous environment. In addition to environmental availability, they were guided in their choice by the mechanical and intrinsic qualities of the woods chosen to manufacture the structure, which they thus fortified meticulously, while avoiding pine trees that they favored for cutting the flooring slats. This search for resistant woods offering long spans and interesting durability for the sandpits and floor beams is perhaps also to be related with the ceremonial function of this reception room.

The floor of the house discovered on the site of Camelin block was heavily infested by woodborers (35\% infestation rate). This finding constitutes an interesting key to understanding the different stages of the deterioration of the structure by fungal colonization owing to humidity from the gutter followed by a second woodborer attack. The history of a wooden structure is here particularly well documented from its genesis to its near collapse stopped by fire.

For the time being, this study remains very isolated for the Mediterranean area. Other points of comparison will undoubtedly help to write a history of wood pests, for these insects are extremely sensitive to climatic conditions. The accumulation of long-term studies should help to enrich the knowledge of environmental conditions in Fréjus and around its territory.

The observation and recording of the traces left by wood-boring insects was systematically carried out on archaeological charcoals. It is a time-consuming approach compared to conventional identification and anatomical observation methods, but it documents the archaeology of the construction and deconstruction of a Roman urban building in an unprecedented way.

\section{Funding}

This work was supported by the French Region Pays de la Loire (PhD grant), OSUR Rennes I University (Photographs MEB by CMEBA-SCANMAT laboratory) and the Archaeological and Heritage Service of Fréjus.

\section{References}

Andrieu-Ponel V., Ponel P., Jull A. J. T., Beaulieu J.-L. de, Bruneton $\mathrm{H}$. and Leveau Ph., "Towards the reconstruction of The Holocene vegetation history of Lower Provence: two new pollen profiles from Marais des Baux», Vegetation History and Archeobotany, 2000a, t. 9, 71-84.

Andrieu-Ponel A., Ponel Ph., Bruneton H., Leveau Ph., 
Beaulieu J.-L. de, «Palaeoenvironments and cultural landscape of the last 2000 years reconstruted from pollen and Coleopteran records in the Lower Rhône Valley, Southern France», The Holocene, 2000b, t. 10, fasc.3, 341355.

Barbero M., Loisel R, Carte écologique des Alpes au 1/100000 Cannes Q. 22, Documents de cartographie écologique, t. XIV, 1974, Université de Grenoble, 81-100.

Beaulieu J.-L. de, Contribution pollen analytique à l'histoire tardi- et post-glaciaire de la végétation des Alpes méridionales françaises, thèse de l'université d'Aix-Marseille III, 1977, 358 p.

Berger P., Coléoptères Cerambycidae de la faune de France continentale et de Corse. Actualisation de l'ouvrage d'André Villiers, 1978. Ed. Association Roussillonnaise d'entomologie (A.R.E.), Perpignan, 2012, 664 p.

Bernabei M., Bontadi J., Rea R., Büntgen U., Tegel W., «Dendrochronological evidence for long-distance timber trading in the Roman Empire», PLoS ONE 14 (12): e0224077. 2019, 13 p. https://doi.org/10.1371/journal. pone. 0224077

Bernard V., " Stratégie d'approvisionnement en bois en Gaule du nord-ouest (du ler siècle avant au IVe siècle après J.-C.) ». Revue archéologique de Picardie, n¹-2, 2003. Cultivateurs, éleveurs et artisans dans les campagnes de Gaule romaine, 77-86.

Blanchette, R.A., Cease, K.R., Abad, A., Koestler, R.J., Simpson, E., Sams, G.K., 1991. An evaluation of different forms of deterioration found in archaeological wood. Int. Biodeterior. 28, 3-22.

Bletchly J. D., "The influence of decay in timber on susceptibility to attack by Anobium punctatum", Annals of Applied Biology, 40, 1953, pp. 218-221.

Blondel F., Girardclos O, « Approche dendroarchéologique de l'approvisionnement de la ville antique d'Augustonemetum (Clermont-Ferrand - Puy-de-Dôme) en bois d'œuvre et exploitation forestière ", ArcheoSciences, 42-1, 2018, 17-33.

Borréani M., Chabal, L. Matthieu L., Michel J.-M., Pasqualini M.,Provansal-Lippman M., « Peuplement et histoire de l'environnement sur les îles d'Hyères (Var) ", Documents d'archéologie méridionale, 15, 1992, pp. 391-416.

Bouby L., Figueiral I, Schaal C., Analyse archéobotanique, Chapitre 3 in: Excoffon P. (dir.), Ville et campagne de Fréjus romaine : La fouille préventive de "Villa Romana ". Aix-en-Provence : Publications du Centre Camille Jullian, 2011, 221-235.

Braun-Blanquet J., La forêt d'yeuse languedocienne, (Quercion ilicis). Monographie phytosociologique, Mémoires de la société d'étude des sciences naturelles de Nimes, $n^{\circ}$ 5, Montpellier, Mari-Lavit, 1936.

Braun-Blanquet J., Roussine N., Nègre R., Les groupements végétaux de la France méditerranéenne, Paris, CNRS, 1952.

Britton Ch., Chabal L., Pagès G., Schneider L., « Approche interdisciplinaire d'un bois méditerranéen entre la fin de l'antiquité et la fin du Moyen Âge, Saugras et Aniane, Valène et Montpellier », Médiévales, 53, automne 2007, 6580.

Buckland P. C., "The use of insect remains in the interpretation of archaeological environments », in: D. A. Davidson \& M. L. Shackley (eds), Geoarchaeology. Earth Science and the Past. London, Duckworth, 1976, 369-396.

Buckland P. C., Coope G. R., A Bibliography and Literature Review of Quaternary Entomology, Collis, Sheffield, 1991, $85 \mathrm{p}$.

Buxó R., Chabal L. et J.-C. Roux, « Toiture et restes incendiés dans l'habitat de Lattes au IVe s. av. n. è. " ; Lattara 9, 1996, 373-398.

Cabanis M., Marguerie D., « Les ressources en bois dans le bassin de Clermont-Ferrand du Néolithique à la période romaine d'après l'analyse dendro--anthracologique ", Quaternaire, 24, (2), 2013, 129-139.

Castelletti L., "I carboni della vetreria di Monte Lecco", Archeologia medievale, t.2, 1975, pp.99-122.

Cenzon-Salvayre C., Le bûcher funéraire dans l'Antiquité : une approche archéologique, bioarchéologique et historique d'après l'étude des structures de crémation en Gaule méridionale, PhD thesis, Le Mans university, https:// halshs.archives-ouvertes.fr/tel-01661126

Chabal L., " Environnement végétal de La Galère (Porquerolles, Var) étude anthracologique ", Documents d'archéologie méridionale 14, 1991, 368-377.

Chabal L., Forêts et sociétés en Languedoc (Néolithique final, Antiquité tardive) : l'anthracologie, méthode et paléoécologie, Paris, Documents d'Archéologie Française, 63, 1997, $189 \mathrm{p}$.

Chabal L., «Étude anthracologique de la place 123 (Lattes IVe s. av. J.-C.) : approche spatiale diachronique », Buxó R., Chabal L., Garseiden A. (dir.), La place 123 recherches pluridisciplinaires sur un espace urbain du IVe s. av. J.-C., Lattara, 2003, 219-242.

Chabal L., " D'où vient le sapin des puits d'Ambrussum ? », Fiches J.-L. (dir.), Quatre puits de l'agglomération routière gallo-romaine d'Ambrussum (Villetelle-Hérault), Montpellier, Éditions de l'association de la Revue archéologique de Narbonnaise (coll. Suppl. à la RAN, 42), 2012, 84-85.

Chabal L., « Le bois dans l'architecture et le mobilier (500475 av. J.-C.) : les boisements aux origines de Lattara », Lebeaupin D. (dir.), Les origines de Lattara et la présence étrusque, les données de la zone 27, Lattara, 22, 2014, 115-165.

Chabal L., « Étude anthracologique de la Capelière et synthèse sur l'histoire des boisements de Camargue, de l'âge du Fer au début du Moyen Âge », Landuré C., Arcelin P., Arnaud-Fassetta G., (dir.), Le village de la Capelière en Camargue du début du Ve siècle avant notre ère à l'Antiquité tardive, 26, Centre Camille Jullian et Presses Universitaires de Provence, Bibliothèque d'Archéologie Méditerranéenne et Africaine (BIAMA), 2019, 363-393.

CTBA (Centre Technique du Bois et de l'Ameublement), Le traitement curatif des bois dans la construction. Département BIOTEC (Biologie, Environnement, Technologies), Paris, ed. Eyrolles, 1996, 140 p.

Delhon C., Thiébault S., "The migration of beech (Fagus sylvatica) up the Rhône: the history of a «mountain» species, Vegetation history and Archaeobotany, 14, 2005, 119-132.

Delobel A., Tran M., Les Coléoptères des denrées alimentaires entreposées dans les régions chaudes. Orstom/ CTA, Paris, (Faune tropicale, 32), 1993, 425 p.

Dubar M., " L'édification de la plaine deltaïque du Bas Argens (Var, France) durant la Protohistoire et l'Antiqui- 
té. Application d'un modèle numérique 2D à l'archéologie ", Méditerranée. Geosystèmes montagnards et méditerranéens. Un mélange offert à Maurice Jorda, 2004, 102, 47-54.

Dubar M., Bui-Thi-Mai, Nicol-Pichard S. et Thinon M., « Étude palynologique du carottage de Pont d'Argens (Roquebrune-sur-Argens, Var) : histoire holocène de la végétation en Provence cristalline ; facteurs naturels et anthropiques », Ecologia Mediterranea, 2004, t. 30, 147-157. Dubar M., Bui-Thi Mai,Girard M., « Évolution de la végétation littorale de la Côte d'Azur (Var et Alpes-Maritimes, France) en relation avec les derniers stades de la remontée du niveau marin à l'Holocène. Esquisse d'un modèle Quaternaire », Quaternaire, 22, 2011, 61-71.

Durand A., « Dynamique biogéographique des boisements Languedoc : l'impact de l'an Mil », Bulletin de la Société botanique de France, 1992, t. 139, 627-636.

Durand A., Vernet J.-L., « Anthracologie et paysages forestiers médiévaux : à propos de quatre sites languedociens », Annales du Midi, 99, n¹80, 1987, 397-405.

Español F. Coll, Fauna Iberica. Vol. 2. Coleoptera: Anobiidae. Departamento de Biologia Animal, Universitad de Barcelona, Museo Nacional de Ciencas Naturales, Consejo Superior de investigaciones cientificas, Madrid, 1992, $196 \mathrm{p}$.

Excoffon P., Cordonnier J., « Fréjus îlot Camelin », Bulletin scientifique régional de la région Provence-Alpes-Côte-d Azur, 2012, 188-189.

Excoffon P., Gaucher G., Joncheray C., « Fréjus, îlot Camelin ", Bulletin scientifique régional de la région Provence-Alpes-Côte-d Azur, 2013, 162-163.

Excoffon P., Lemoine Y., Gaucher G., Pellegrino E., Joncheray C., Leguilloux M., « Un foyer, des amphores et une poêle à frire... un espace culinaire à Fréjus dans Histoires matérielles : terre cuite, bois, métal et autres objets ». Des pots et des potes : Mélanges offerts à Lucien Rivet, Archéologie et Histoire Romaine, 33, 2016, 349-358.

Excoffon P., Vauxion O., " Les enduits peints de l'îlot Camelin à Fréjus, J. Boislève, A. Dardenay, F. Monier (eds.), Peintures murales et stucs d'époque romaine. Une archéologie du décor. Actes du 27e colloque de l'AFPMA, Toulouse, novembre 2014, 2016 (Pictor, 5), 59-74.

Excoffon P., Bonnet S. en collaboration avec Tomatis C., Ferrer L., Ardisson S., Bernigaud N., Portalier N., et Morhange C., " Restitution de la morphologie littorale et aménagements portuaires de Forum Iulii ", Sanchez C. et Jezegou M.-P. (dir.), Les ports dans l'espace méditerranéen antique. Narbonne et les systèmes portuaires fluvio-lagunaires, Montpellier, Supplément de la Revue archéologique de Narbonnaise, 44, 2016, 339-352.

Fancelli-Galletti M.-L., I «carboni della grotta delle arene candide e l'evoluzione forestale in Liguri dopo l'ultima glaciazione», Atti Soc. Tosc. Sci. Nat. Mem., serie A, 79, 1972, 206-212.

Fohrer F., Toriti M., Durand A., « Analyse des vermoulures pour la détermination de quelques espèces d'Insectes $x y$ lophages de la famille des Ptinidae (Coleoptera) », Bulletin de la société entomologique de France, 122 (2), 2017, 133-142.

Greguss, P., Identification of living Gymnosperms on the basis of xylotomy. Budapest: Akadémiai Kiadó, 1955.

Greguss, P., Holzanatomie der europäischen Laubhöl- zerund Sträucher. Budapest: Akadémiai Kiadó, 1959.

Guillon S., Analyses polliniques des structures agraires. Chapitre 4, in: Excoffon P. (dir.), Ville et campagne de Fréjus romaine: La fouille préventive de "Villa Romana ». Aix-en-Provence : Publications du Centre Camille Jullian, 2011, 237-243

Hall, A. Kenward H., Rousseau M. et Bain A., «The Environmental archaeology of Urban Landscape», Smith C. (ed), Encyclopedia of Global Archaeology, Springer Sciences, New York, 2014, 77-82.

Huchet, J.-B., « L'Archéoentomologie funéraire : une approche originale dans l'interprétation des sépultures ", Bulletins et Mémoires de la Société d'Anthropologie de Paris, 8 (3-4) 1996 : 289-302.

Huchet, J.-B., "Insectes et archéologie ", Les nouvelles de l'archéologie [En ligne], 148 | 2017, 11 p. http://journals. openedition.org/nda/3722; DOI : 10.4000/nda.3722

Jacquiot C., Atlas d'anatomie des bois des Conifères, $\mathrm{Pa}$ ris, Centre technique du bois, 1955.

Jacquiot C., Trenard Y., Dirol D., Boureau M.-E., Atlas d'anatomie des bois, les Angiospermes. Paris : Centre technique du bois, tome I, 1973, $175 \mathrm{p}$.

Kenward H, «Further Archaeological Records of Aglenus Brunneus (Gylll.) in Britain and Ireland. Including Confirmation of its Present in the Roman Period», Journal of Archaeological Science, 3, 1976, 275-277.

Küster H., «The economic use of Abies wood as timber in central Europe during Roman times», Veget Hist Archaeobot (1994) 3: 25-32.

Laclos É. de, Büche B., « La vrillette sans peine : première note (Coleoptera Anobiidae) ». L'Entomologiste, 64 (1), 2008, 3-10.

Lamouille S., Péfau P., Rougier-Blanc S. dir., « Bois et architecture dans la Protohistoire et l'Antiquité (XVle av. J.C; - Ile s. apr. J.-C) », Pallas, n¹10, 2019.

Lepesme P., Les Coléoptères des denrées alimentaires et des produits industriels entreposés, Lechevalier, Paris, 1944, 335 p., 12 pl. Encyclopédie Entomologique, 22).

Liottier L., Bois et forêts en France méditerranéenne durant la Protohistoire : une approche des pratiques et des usages. Études anthracologique, dendroécologique et spatiale, thèse de l'université de Montpellier III, 2019.

Moret, P. 1998. "L'archéo-entomologie, ou les insectes au service de l'histoire ", Revue de médecine vétérinaire 149 (11) : 995-998. https://hal.archives-ouvertes.fr/hal00723967

Moser D., Nelle O. and Di Pasquale G., "Timber economy in the Roman Age: charcoal data from the key site of Herculaneum (Naples, Italy)", Archaeological and Anthropological Sciences, 10, 2018, 905-921.

Nichol-Pichard S., « Analyse pollinique d'une séquence à Tourves (Var-France) », Ecologia Mediterranea, 1987, XIII, 1-2, 29-42.

Nichol-Pichard S. et Dubar M., «Reconstruction of late-glacial and holocene environments in southeast France based on the study of a 66-m long core from Biot, Alpes Maritimes», Vegetation History and Archaeobotany, 1998, 7, 11-15.

Ozenda P., La végétation de la chaîne alpine dans l'espace montagnard européen, Paris, Masson, 1985, 344 p. Planchais N., « Palynologie lagunaire de l'étang de Mauguio. Paléoenvironnement végétal et action anthropique », 
Pollen et spores, 1982, 21, 73-118.

Planchais N., « Impact de l'homme lors du remplissage de l'estuaire du Lez (Palavas, Hérault) », Pollen et spores, 1987, 29, 73-88.

Ponel Ph., «La Tène and Gallo-Roman Natural Environments and Human Impact at the Touffréville Rural Settlement, Reconstructed from Coleoptera and Plant Macroremains (Calvados, France)», Journal of Archaeological Science 27, 2000, 1055-1072, doi:10.1006/jasc.1999.0514 Ponel Ph., Analyses entomologiques (coléoptères), Chapitre 5 in: Excoffon P. (dir.), Ville et campagne de Fréjus romaine : La fouille préventive de "Villa Romana ». Aix-enProvence : Publications du Centre Camille Jullian, 2011, 245-256.

Puertas O., "Palynologie dans le delta du Lez. Contribution à l'étude du paysage de Lattes », Lattara 11, Lattes, ARALO, 1998.

Quézel P., Médail F., Écologie et biogéographie des forêts du bassin méditerranéen, Elsevier, Collection Environnement, Paris, 2003, $573 \mathrm{p}$.

Schweingruber, F.H., Anatomie europäischer Hölzer; anatomy of European woods. Haupt, éd: WSL-FNP, 1990, 800

p.

Triat-Laval H., Contribution pollen analytique à l'histoire tardi- et post-glaciaire de la végétation de la Basse Vallée du Rhône, Thèse Etat, Université d'Aix-Marseille III, 1978. Toriti M., Les bois ouvragés en Gaule romaine : approches croisées archéologiques, anthraco-xylologiques et entomologiques, $\mathrm{PhD}$ Thesis, Le Mans University, unpublished, 2018, 1052 p. https://halshs.archives-ouvertes.fr/ tel-02382217.

Toriti M., Durand A., Fohrer F., « Les bois carbonisés de la zone de l'entrepôt : approches croisées anthracologiques et paléoentomologiques ", Bouet A. (dir.), Les fouilles des entrepôts de Barzan, Barzan IV, Bordeaux, Ausonius édi- tion, 2020a, 479-486.

Toriti M., Durand A., Fohrer F., «Into timber: revealing xylophagous Roman insects through archaeoentomological analysis; the fluvial port of Ratiatum (Rezé Saint-Lupien, France)», Environmental Archaeology, 2020b accepted for publication.

Veal R., "The politics and economics of ancient forests: timber and fuel as levers of Greco-Roman control», [Academic Journal], In Derron, P. Hardt Foundation, Economie et inégalité: Ressources, échanges et pouvoir dans l'Antiquité classique. [Book chapter], 317-367. https://doi. org/10.17863/CAM.13218

Venot-Tisserand C., Bois, forêt et environnement en Basse-Provence médiévale : archéologie et bioarchéologie des usages et des procédés de gestion de l'inculte, PhD Thesis, Aix-Marseille University, 2016, unpublished.

Vernet J.-L., Contribution à l'histoire de la végétation du Sud-Est de la France au Quaternaire, étude de macroflores de charbons de bois principalement. Thèse d'état, Université des Sciences et Techniques du Languedoc, Montpellier, 1973, $104 \mathrm{p}$.

Violino J.-P., Bui-Thi-Mai, Dubar M., Cataliotti-Valdina J., « Environnement et occupation humaine Bas-Lauvert (Antibes) », Revue archéologique de Narbonnaise, 26, 1993, 247-257.

Western A. C., "Wood and charcoal in Archeology», D. Brothwell and E. Higgs, ed., Science in Archeology, Bristol, Thames and Hudson, 1963, 150-160.

Western A. C., "The ecological interpretation of ancient charcoals from Jericho», Levant, t.III, 1971, British School of Archeology in Jerusalem, 31-40.

Willcox G., «A history of deforestation as indicated by charcoal analysis of four sites in Eastern Anatolia», Journal of the British Institute of Archeology at Ankara, 1974, 117-133. 